\title{
The Tourist Harassment Based on the Marketing
}

\author{
Ji Wen, Yina Li \\ Jinan University, Guangdong, China \\ Email: 545987613@qq.com, liyina1992@163.com \\ Received 11 February 2015; accepted 16 March 2015; published 18 March 2015 \\ Copyright (C) 2015 by authors and Scientific Research Publishing Inc. \\ This work is licensed under the Creative Commons Attribution International License (CC BY). \\ http://creativecommons.org/licenses/by/4.0/

c) (7) Open Access

\begin{abstract}
The marketing innovation includes not only the innovation of production quality, but also the innovation of service. According to the foreign literatures and the past solution of tourist harassment, this paper emphasizes the importance of tourist harassment. "No harassment" can be a bright spot of destination marketing. The purpose of this paper is to propose a new and novel solution for destination marketing in a different prospect. The situation without production innovation can be promoted by the idea of traveling with no harassment.
\end{abstract}

\section{Keywords}

\section{Marketing, Tourist, Harassment, Tourist Destination}

\section{Introduction}

Tourism has become an important way of leisure in the modern time; with super improvement of economy and more convenience of traffic, the tourists almost cover all persons who have right to do what he wants to do. Due to the characteristics of nonresident, a series of effects of tourism act on the destinations directly, like economic, social and environmental effects. Now, more scholars have concentrated on studying the factors which affect tourists where they should go. Generally, it includes two parts. One is about tourists, like the leisure time, disposable money and so on; the other is about the destinations, such as the tourism resource, accessibility and safety.

The research about tourists has an in-depth discussion already, but the research about harassment is only at an early stage. For most tourists, tourism harassment will reduce their satisfaction obviously, and related research is also limited. So, this paper will discuss the harassment in perspective of marketing.

In 2003, King came up with closely four of fifth tourists who had the experience of harassment from local vendors during their travel in Barbados [1]. In addition, the first tourism survey about Barbados has shown that 
more than $60 \%$ participants have this kind of experience [2]. Tourism harassment is defined by Ralph Carnegie as the following: In the destination, the vendors peddle a lot of goods even drug to tourists constantly and it causes more interference about tourists [2].

In fact, traveling is an opportunity to obtain an experience of leisure, but this harassment will affect this feeling and the impression about the destination. And in depth, it will hurt the revisit rates and the image of destination. So, it requires controlling this question and it is important for the marketing of destination.

\section{Literature Reviews}

\subsection{The Progress of Foreign Research about Tourism Harassment Tourism Crime}

Tourism has changed the social economic structure, and at the same time it also increased the crime rates of destinations [3]. Ryan definite tourism crime as: "The behavior which are contrary to local laws and caused by the tourism activities or happening during tourism" [4].

Klaus de Albuquerque found, due to the low precaution awareness, tourists have more easier to become the targets than the local residents, especially the property crime [5]. The more frequently the crime happened, the less tourists are.

The reasons of harassments have included three aspects. The first, level of tourists' consumption are higher than the locals obviously. The second, the locals feel unfair about the unbalance between tourists and them. The last one is discrimination of areas [6].

Tourism crime is not only affecting tourists, but also prevents the investment by most developers. Charles found $90 \%$ managers considered the safety as an important factor which decide whether to invest. At the same time, Robotham thought the safety erode the social capitals [7].

\subsection{Tourism Harassment}

Boxill did a random sampling survey and found that only $2 \%$ participants considered the crime as the first confusion in their tourism, most of them thought the worst infrastructure and harassment from the local vendors are the main problems [8].

Tourism harassment means that do something makes tourists unhappy, the person who carry out the behaviors are the local vendors or others. Klaus de Albuquerque and Jerome L. McElroys were the first ones to research this issue. Some of conclusions about this question are included [2]:

1) There is no obvious relationship between the harassment and victim's gender.

2) Tourists who visited firstly are attacked more than the one who are veterans.

3) The people from surrounding areas have lower rates to be harassed, because they have more similarity with the local people.

Harassment can be classified for five styles: first, the vendors ask tourists to visit shop or pestered to make a purchase; second, sexual harassment; third, verbal abuse; fourth, body attack; fifth, the crime-oriented matter of dealings in relation to drugs. Metin Kozak analyzed that harassment from vendors are the dominated problem, and the most frequent places were beach and street [9].

This issue has seriously influenced the development of tourism, but it is not paid attention to that yet. The reasons are included that this behavior is difficult to definite and collect the evidence [10].

The progress of domestic research about tourism harassment.

Based on foreign research achievement, domestic scholars Shao Ruijuan found that the local people want to make money from the tourists who were considered as the rich as a compensation. This is the reason why harassment happened. The bigger the gap between rich and poor, the more harassment were happened [9].

Pro. Zheng Xiangmin analyzed the degree of safety of destination from four aspects which included female psychological sense of insecurity, unsafe tourism behavior, safety event and prevention. It is only tourists' perspective, not refer to marketing perspective [11].

\section{Analysis of Tourism Harassment and Marketing Strategy}

\subsection{Analyze the Harassment Based on Perspective of Vendors}

To get through this issue, we analyze tourism harassment from different perspectives. For the tourists, travel is 
an experience which can relax them, so they don't be disturbed by others.

On the contrary, those vendors consider "the harassment" as an excellent sale skill, and think they have right to sale on the public street. Secondly, the local people take more care of making living than tourism. Lastly, they consider tourists as the rich, and they can give some happiness to tourists for selling and also can get economic and physical compensation [9].

It is reasonable in some degrees, but it is a vicious cycle in fact that it cause dissatisfied for the tourists. And then it will cause serious economic loss and bad image for the destination. So it is necessary to regulate for the government or related department.

\subsection{Solution of Tourism Harassment}

The negative effects of tourism harassment have been found by the local investor, and they have already taken actions to reduce it. For example, in Caribbean, increasing number of plainclothes polices to keep order in hot spots, to control or stop the behavior of harassment, to punish the vendors with no license. Or increasing point of sale to sell souvenirs. These measures can be effective in short term, but it doesn't enough to do so. In other aspect, it will make tourists nervous to see lots of police and given them a bad image about the destination.

Sandals, Couples and Hedonism had proposed a model called "Enclave Tourism" to reduce the cases of harassments [5]. Enclave tourism means the employees come from other place or the tourists consume at other places out of destinations. It can be separated tourists and local people in theory, and local people can not get any economic benefits from tourists, and no harassed behavior happened. But, in fact, if there is no benefit local people can get, the relationship will be deteriorated between tourists and them. The local people do not cooperate with government to develop the tourist, even block it.

In the long term, to consummate the legal system and courage community involvement can be solved it fundamentally. What a good way to deal with the harassment is to organize all stakeholders of tourist to set up a committee to deal with the related issues [10]. Firstly, the committee should propagandize and educate the local people and let them know the importance of tourist for their economic development. Secondly, it needs to set up a complaint center to deal with complaint and punish the person who are complained and increase the satisfaction of consumers. Lastly, long-term measures are in combination with the short-term action can have a sustainable way to develop the destination [12].

\subsection{Revelation of Marketing}

With the popularization of tourism and increase of people's income, the competition becomes more and more fierce. To attract more tourists, it should have some creative ideas besides better infrastructures and tourism production. What we need to do is changing the perspective of innovation; from the aspect of helping tourists to solve problems, they encounter instead of only optimize productions. No harassment can give them an excellent environment to relax themselves, and also can have sense of safety.

From this paper, if the harassment can be solved, it will be the best service for tourists and it also can be as a highlight in the advertisement. Let more people know that we can provide a free, no disturbed, and relax travel experience for you besides sightseeing. It emphasizes no harassment as our characteristic.

\section{References}

[1] King, J. (2003) The Perceptions of Crime and Safety among Tourists Visiting the Caribbean. In Harriott, A., Ed., Understanding Crime in Jamaica, University of West Indies Press, Kingston, 157-175.

[2] de Albuquerque, K. and McElroy, J.L. (2001) Tourist Harassment: Barbados Survey Results. Annals of Tourism Research, 28, 477-492. http://dx.doi.org/10.1016/S0160-7383(00)00057-8

[3] Jones, A. (1993) Sustainability and Community Participation in Rural Tourism. Leisure Studies, 12, 147-148. http://dx.doi.org/10.1080/02614369300390131

[4] Ryan, C. (1993) Crime, Violence, Terrorism and Tourism. An Accidental or Intrinsic Relationship? Tourism Management, 14, 173-183. http://dx.doi.org/10.1016/0261-5177(93)90018-G

[5] de Albuquerque, K. and McElroy, J. (1999) Tourism and Crime in the Caribbean. Annals of Tourism Research, 26, 968-984. http://dx.doi.org/10.1016/S0160-7383(99)00031-6

[6] Xia, S. (2012) The Reason of Tourist Crime. Special Zone Economy, 7, 189-191. 
[7] Clayton, A. and McDavid, H. (2004) The Impact of Terrorism and Extortion on Engineering Construction and Development. Paper Presented at the 25th Annual Conference of the American Society for Engineering Management, Alexandria.

[8] Ajagunna, I. (2006) Crime and Harassment in Jamaica: Consequences for Sustainability of the Tourism Industry. International Journal of Contemporary Hospitality Management, 18, 253-259. http://dx.doi.org/10.1108/09596110610658652

[9] Kozak, M. (2007) Tourist Harassment: A Marketing Perspective. Annals of Tourism Research, 34, 384-399. http://dx.doi.org/10.1016/j.annals.2006.10.003

[10] McElroy, J.L., Tarlow, P. and Carlisle, K. (2007) Tourist Harassment: Review of the Literature and Destination Responses. International Journal of Culture, Tourism and Hospitality Research, 1, 305-314. http://dx.doi.org/10.1108/17506180710824190

[11] Zheng, X.M. and Fan, X.L. (2008) Progress and Revelation of Travel Safety of Females. General Information, 3, 102108.

[12] Shao, R.J. and Lu, L. (2008) Progress and Revelation of Tourists’ Harassment. Resource of Tourism, 24, $1034-1037$. 